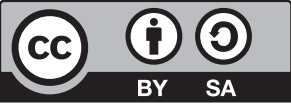

PRZEMYStAW KRAWCZYK Uniwersytet Wrocławski

BARTOSZ ŁUKOWIAK Uniwersytet Wrocławski
iD https://orcid.org/0000-0002-5462-3540

iD https://orcid.org/0000-0003-3993-2182

\title{
Habeas corpus w Polsce oraz w niektórych państwach kręgu common law Analiza prawnoporównawcza
}

\begin{abstract}
In their article, Przemysław Krawczyk and Bartosz Łukowiak discuss the issue of the habeas corpus procedure. On the basis of a comparative legal analysis, they present a model of the functioning of this institution in Poland and in selected countries whose legal code is based on common law. Krawczyk and Łukowiak discuss in detail, among other things, the scope and the subject matter of this mode and the catalogue of guarantees associated with it. Their research has made it possible to compare the most important similarities and differences in the functioning of the habeas corpus privilege in the Polish legal code and in common law. This, in turn, has allowed them to assess the accuracy of some of the solutions known to the Polish criminal procedural law. This article contains extensive references to the views expressed on this mode both in the Polish and the AngloSaxon doctrine of the procedural criminal law and to the case law of the European Court of Human Rights and the United States Supreme Court.
\end{abstract}

Keywords: habeas corpus, arrest, detention on remand, coercive measures, criminal proceedings, common law, comparative law

\section{Wprowadzenie}

W ostatnim ćwierćwieczu do rangi jednego z najbardziej interesujących zagadnień z zakresu środków przymusu stosowanych w procesie karnym urosło zagadnienie tzw. postępowania habeas corpus, powiązanego z określonymi gwarancjami przysługującymi jednostce w związku z pozbawieniem jej przez organy państwa wolności osobistej. Bez wątpienia 
wynika to z jednej strony z ratyfikowania przez Rzeczpospolitą Polską w 1993 r. Europejskiej Konwencji Praw Człowiekaª , której przyjęcie do krajowego porządku prawnego wiązało się m.in. $\mathrm{z}$ inkorporowaniem poświęconego tej procedurze art. 5 ust. 3 i $4 \mathrm{EKPCz}$, a z drugiej z mającego miejsce w zbliżonym czasie uchwalenia Konstytucji RP², która - mówiąc najoględniej - zapewniła jednostce zdecydowanie szerszą ochronę przed bezprawnym pozbawieniem wolności ze strony aparatu państwowego aniżeli poprzednio obowiązująca ustawa zasadnicza. W tym samym okresie trwały zresztą prace nad obecnie obowiązującym Kodeksem postępowania karnego ${ }^{3}$, które niewątpliwie także przyczyniły się do wzrostu zainteresowania tą tematyką.

Pomimo upływu ponad 25 lat od przywołanych wydarzeń przedstawicielom doktryny prawa karnego procesowego w dalszym ciągu nie udało się osiągnąć porozumienia nawet $\mathrm{w}$ takich kwestiach, jak choćby sama definicja habeas corpus. Wątpliwości budzi zresztą sam genus takiej definicji, ponieważ analizowane pojęcie bywa definiowane za pomocą przeróżnych określeń. Według najbardziej ogólnych ujęć habeas corpus to rodzaj „instytucji”, „koncepcji”, „idei” czy „zasady”, zaś według nieco bardziej konkretnych definicji jest to rodzaj „standardu”, „gwarancji”, „przywileju” czy „wymogów” (perspektywa materialnoprawna) albo też typ „postępowania” czy „procedury” (perspektywa procesowa). W toku dalszych wywodów zasadniczo przyjęto perspektywę procesową, jednak w zależności od kontekstu - nie wystrzegając się przy tym pewnych uproszczeń mowa jest również o habeas corpus w znaczeniu koncepcji lub zbioru gwarancji.

Część badaczy wiąże omawiane pojęcie z uprawnieniem do oczekiwania, że decyzję w przedmiocie zastosowania tymczasowego aresztowania w toku całego procesu karnego będzie podejmował wyłącznie niezależny organ sądowy ${ }^{4}$. Niektórzy autorzy upatrują jego istoty w prawie do udziału $\mathrm{w}$ posiedzeniu sądu rozpoznającego zażalenie na zatrzymanie ${ }^{5}$ albo

${ }^{1}$ Konwencja o Ochronie Praw Człowieka i Podstawowych Wolności sporządzona w Rzymie dnia 4 listopada 1950 r., zmieniona następnie Protokołami nr 3, 5 i 8 oraz uzupełniona Protokołem nr 2. Dz.U. 1993, nr 61, poz. 284 ze zm. [Dalej: EKPCz lub Konwencja].

2 Ustawa z dnia 2 kwietnia 1997 r. - Konstytucja Rzeczypospolitej Polskiej. Dz.U. 1997, nr 78, poz. 483, Dz.U. 2001, nr 28, poz. 319, Dz.U. 2006, nr 200, poz. 1471, Dz.U. 2009, nr 114, poz. 946.

${ }^{3}$ Ustawa z dnia 6 czerwca 1997 r. - Kodeks postępowania karnego. Dz.U. 2020, poz. 30 ze zm. [Dalej: k.p.k.].

${ }^{4}$ A. Murzynowski: Refleksje na temat zmian $w$ przepisach dotyczacych stosowania tymczasowego aresztowania. „Prokuratura i Prawo” 1997, nr 1, s. 8; J. Kosonoga: Dozór Policji jako środek zapobiegawczy w polskim procesie karnym. Warszawa 2008, s. 45.

5 S. Waltoś, P. Hofmański: Proces karny. Zarys systemu. Warszawa 2013, s. 414-415. 
$\mathrm{w}$ prawie do samego zainicjowania postępowania sądowego w celu zbadania legalności pozbawienia wolności ${ }^{6}$. Zdaniem jeszcze innych sens tej instytucji sprowadza się do konieczności doprowadzenia zatrzymanego do sądu. Wydaje się, że na ten moment w opisywanym zakresie za przesądzoną można uznać co najwyżej niecelowość tłumaczenia tego pojęcia na język polski.

Zasadniczym przedmiotem sporu jest jednak to, czy w obowiązującym ustawodawstwie w ogóle przyjęto koncepcję habeas corpus (choć warto odnotować, że na wyrażane w tym zakresie stanowiska zasadniczy wpływ mają przyjęte założenia terminologiczne). Zgodnie z pierwszym poglądem, ustawodawca implementował omawiany rodzaj procedury do polskiego procesu karnego „niemal dosłownie”. Zwolennicy przeciwnego stanowiska uważają, że w rodzimym porządku prawnym nie sposób odnaleźć klasycznej instytucji habeas corpus ${ }^{9}$. Wreszcie w myśl stanowiska pośredniego, nie zawsze zresztą wyrażanego wprost, de lege lata doszło do jej jedynie częściowej recepcji na grunt polskiego systemu prawnego ${ }^{10}$.

${ }^{6}$ B. GronowsKa: Wolność i bezpieczeństwo osobiste $w$ sprawach karnych $w$ świetle standardów Rady Europy (implikacje praktyczne dla prawa polskiego). Toruń 1996, s. 96.

${ }^{7}$ J. IZYDORCZYK: Stosowanie tymczasowego aresztowania $w$ kontekście instytucji Habeas Corpus, prawo do obrony. W: P. WilińsKI et al.: Stosowanie tymczasowego aresztowania $w$ Polsce. Analiza i rekomendacje. Raport. Lublin-Poznań-Warszawa 2008, s. 40; w jednej z późniejszych publikacji autor ten definiuje zasadę habeas corpus jako wymóg, aby o ewentualnym i każdorazowym pozbawieniu człowieka wolności decydował wyłącznie niezależny sąd oraz niezawisły sędzia (J. IzydorczyK: Zasada Habeas Corpus jako wzorzec respektowania prawa do wolności a aktualne prawo polskie. W: Verba volant, scripta manent. Proces karny, prawo karne skarbowe i prawo wykroczeń po zmianach z lat 2015-2016. Ksiega pamiatkowa poświęcona Profesor Monice Zbrojewskiej. Red. T. GrzegorczyK, R. OlszewsKi. Warszawa 2017, s. 97); P. HоғмAŃsкI, S. ZAвŁOcKI: Pozbawienie wolności w toku procesu karnego. Wybrane aspekty konstytucyjne i prawnomiędzynarodowe. W: Rzetelny proces karny. Księga jubileuszowa Profesor Zofii Świdy. Red. J. SKORUPKA. Warszawa 2009, s. 513.

${ }^{8}$ Zob. m.in. S. Waltoś, P. Hofmański: Proces karny..., s. 415 - autorzy wskazują, że stało się to na skutek uwzględnienia Wyroku Trybunału Konstytucyjnego z dnia 6 grudnia 2004 r. SK 29/04, OTK-A 2004, nr 11, poz. 114, dotyczącego niekonstytucyjności niezagwarantowania zatrzymanemu lub jego obrońcy albo pełnomocnikowi wzięcia udziału w postępowaniu dotyczącym zażalenia na zatrzymanie.

9 J. IzYDORCzYK: Stosowanie tymczasowego aresztowania..., s. 40; IDEM: Stosowanie tymczasowego aresztowania w polskim postępowaniu karnym. Kraków 2002, s. 34 [przyp. 18]; S. MajCheR, D. STAChURSKI: Sądowa kontrola zatrzymania w świetle Konstytucji RP. „Państwo i Prawo" 2006, nr 4, s. 47, 61; K. EICHSTAEDT: Czynności kontrolne sqdu w postępowaniu przygotowawczym. W: IDEM: Czynności sqdu $w$ postępowaniu przygotowawczym $w$ polskim prawie karnym. Warszawa 2008 [pkt 6.3], Legalis; Ł. CoRA: Zatrzymanie osoby w polskim procesie karnym. Analiza dogmatyczno-prawna. Warszawa 2015, s. 299.

10 Zob. m.in. P. Kardas: Upływ określonego w art. 41 ust. 3 Konstytucji i w art. 248 § 2 k.p.k. 24-godzinnego terminu a możliwość wydania postanowienia o tymczasowym aresztowaniu. „Czasopismo Prawa Karnego i Nauk Penalnych” 2008, z. 1, s. 127; por. P. Hofmański: Europejskie standardy $w$ zakresie kontroli stosowania przymusu $w$ procesie karnym a refor- 


\section{Cel pracy oraz zastosowana metoda badawcza}

Podstawowym celem pracy jest ocena trafności niektórych z zawartych $\mathrm{w}$ polskiej ustawie procesowej rozwiązań dotyczących pozbawiania wolności dla celów procesowych, wykazujących silny związek z ideą habeas corpus. Pomocna w tym zakresie może się okazać analiza kształtu, $\mathrm{w}$ jakim postępowanie to funkcjonuje w niektórych państwach opartych na systemie prawnym common law. To tam zrodziła się jego idea, stąd też wydaje się, że to właśnie tamtejszy model stanowił pierwowzór albo co najmniej „inspirację” dla przyjęcia art. 5 ust. $3 \mathrm{EKPCz}^{11}$. Okoliczność ta prowadzi z kolei do wniosku, że regulacje znane $\mathrm{z}$ systemów prawnych części krajów anglosaskich powinny być przydatne zarówno $\mathrm{w}$ procesie wykładni stosownych postanowień Konwencji (a w konsekwencji również przy ocenie zachowania przez polskiego prawodawcę standardu z niej wynikającego), jak i w analizach stricte naukowych, związanych np. z poszukiwaniem optymalnego kształtu procedury. To ostatnie zadanie zdaje się mieć szczególne znaczenie zwłaszcza w Polsce, ponieważ istotna część tzw. polskich spraw przed Europejskim Trybunałem Praw Człowieka (ETPCz) w Strasburgu dotyczy właśnie niewłaściwego stosowania środków przymusu w procesie karnym (w tym zwłaszcza długotrwałego tymczasowego aresztowania $)^{12}$. Tym bardziej, że w aktualnym ustawodawstwie można

ma kodeksu postępowania karnego. W: Problemy kodyfikacji prawa karnego. Księa ku czci Profesora Mariana Cieślaka. Red. S. Waltoś. Kraków 1993, s. 452-453; za niejasne należy uznać stanowisko wyrażone przez Janusza Wałacha w rozprawie doktorskiej (J. WAŁAcH: „Uprawnienia procesowe zatrzymanego i tymczasowo aresztowanego w świetle zasady prawa do obrony", [rozprawa doktorska]. Opieka nauk. C. Kulesza. Katedra Postępowania Karnego, Wydział Prawa, Uniwersytet w Białymstoku, Białystok 2014), który wskazuje, że art. $246 \S 1$ oraz art. $252 \S 1$ i 3 k.p.k. wypełniają ideę habeas corpus (s. 46), by dalej stwierdzić: „Ustawodawca nie przyjął w nowym kodeksie postępowania karnego z 1997 r. procedury habeas corpus" (s. 88).

11 Warto w tym miejscu odnotować, że prawo polskie gwarantowało części społeczeństwa nietykalność osobistą już w pierwszej połowie XV w., kiedy to za sprawą przywileju jedleńsko-krakowskiego przyjęto formułę neminem captivabimus nisi iure victum (łac.; nikogo nie uwięzimy bez wyroku sądowego), która w istocie znacząco przypominała ideę habeas corpus. Nie powinno jednak budzić wątpliwości, że - m.in. z uwagi na wymuszony sytuacją polityczną brak ciągłości pomiędzy dawną oraz obecną polską tradycją prawną - aktualne rozwiązania ustawowe nie stanowią bezpośredniej kontynuacji formuły neminem captivabimus nisi iure victum, nawiązując raczej do unormowań konwencyjnych, opartych w głównej mierze na regulacjach znanych z państw anglosaskich (por. J. IzYDorczyK: Zasada Habeas Corpus..., s. 98); zob. jednak: Orzeczenie Sądu Najwyższego z 27 stycznia 1921 r. LEX nr 1674571 - w którym najwyższa instancja sądowa odwołała się wprost do „odwiecznej polskiej zasady »neminem captivabimus nisi jure victum «".

12 Zamiast wielu zob. J. SKоRUPKA: Konstytucyjny i konwencyjny standard tymczasowego aresztowania. „Państwo i Prawo” 2007, nr 7, s. 59-69 oraz przywołane tam orzeczenia ETPCz zapadłe w sprawie skarg wniesionych przeciwko Polsce. 
zauważyć tendencję do systematycznego łagodzenia warunków uprawniających organy państwa do korzystania ze środków przymusu skutkujących pozbawieniem lub co najmniej ograniczeniem wolności ${ }^{13}$.

Ocena trafności rozwiązań, na których w omawianym zakresie oparty jest polski proces karny, została przeprowadzona $\mathrm{w}$ artykule poprzez ich zestawienie z rozwiązaniami zagranicznymi. Stąd też w toku dalszych wywodów posłużono się przede wszystkim metodą prawnoporównawczą, koncentrując się na analizie porządku prawnego bodaj najbardziej reprezentatywnych państw (lub ich części) kręgu common law, tj. Wielkiej Brytanii, USA oraz - w pewnym zakresie - Kanady. Od razu warto odnotować, że prawodawstwo państw systemu common law jest wewnętrznie niezwykle zdywersyfikowane. Na system prawa Zjednoczonego Królestwa Wielkiej Brytanii i Irlandii Północnej składają się prawo angielskie, szkockie, walijskie i północnoirlandzkie. Również w Kanadzie każda prowincja (i każde terytorium) dysponuje swoistym porządkiem prawnym, przez co funkcjonuje tam 13 różnych systemów, z których każdy - z wyjątkiem Quebecu - w przeważającej mierze oparty jest na elementach common law. Z kolei w USA wyróżnia się aż 53 systemy prawa ${ }^{14}$, w skład których wchodzą system federalny, systemy poszczególnych stanów, prawo Dystryktu Kolumbii oraz tzw. prawo terytoriów. Stąd też za konieczne należy uznać omówienie funkcjonowania w tych krajach tzw. writ of habeas corpus jedynie w sposób ogólny, pozwalający na wykazanie podobieństw i różnic w odniesieniu do jego odpowiednika w polskim procesie karnym. Zestawienie podobieństw i różnic przyczyni się do wychwycenia ewentualnych nieprawidłowości w polskim procesie karnym, których objaśnienie posłuży do sformułowania w końcowej części pracy stosownych wniosków de lege ferenda.

Warto podkreślić, że zasadniczym celem pracy nie jest ocena zgodności unormowań polskich z Konwencją. Wynika to z kilku założeń. Po pierwsze, rozwiązania wielostronnych konwencji międzynarodowych świadomie regulowane są na pewnym poziomie ogólności. Ma to służyć $\mathrm{z}$ jednej strony uwzględnianiu tradycji prawnych różnych państw-stron, co zasadniczo byłoby niemożliwe $\mathrm{w}$ razie regulowania określonych instytucji prawnych na poziomie międzynarodowym w sposób całościowy (wyczerpujący), a z drugiej strony - „zniechęcaniu” przedstawicieli poszczególnych państw do składania przy podpisywaniu danego traktatu licznych zastrzeżeń w trybie art. 19 Konwencji wiedeńskiej o prawie trak-

${ }_{13}$ Zob. chociażby art. 15a Ustawy z dnia 6 kwietnia 1990 r. o Policji (Dz.U. 2020, poz. 360), wprowadzony Ustawą z dnia 30 kwietnia 2020 r. o zmianie ustawy - Kodeks postępowania cywilnego oraz niektórych innych ustaw. Dz.U. 2020, poz. 956.

${ }_{14}$ Z. HoŁDA: Z problematyki gwarancji procesowych podejrzanego $w$ świetle konstytucji USA. „Annales Universitatis Mariae Curie-Skłodowska. Sectio G” 1983, nr 9, s. 141. 
tatów ${ }^{15}$, co per se osłabiałoby efektywność systemu praw człowieka bardziej aniżeli ogólność norm wchodzących w jego skład. Po drugie, art. 5 ust. 3 EKPCz wyznacza jedynie minimalny standard analizowanego postępowania. Nie budzi wątpliwości, że ustawodawca nie powinien ograniczać się do dostosowania krajowego prawodawstwa do tego minimum, ale próbować poszukać rozwiązań optymalnych, wykraczających poza zakres ochrony przewidziany w Konwencji. Po trzecie, zawarta w tekście analiza prawnoporównawcza odnosi się również do porządku prawnego państw niebędących stroną Konwencji. Wydaje się, że łączne omówienie postępowania habeas corpus na gruncie konwencyjnym i poza nim prowadziłoby z jednej strony do istotnego zaburzenia spójności konstrukcyjnej pracy, a z drugiej albo do powierzchowności analizy, albo do przekroczenia dopuszczalnych ram artykułu. Pozostaje jedynie wyrazić nadzieję, że zarysowana $\mathrm{w}$ opracowaniu tematyka stanie się $\mathrm{w}$ przyszłości przedmiotem pozycji monograficznej, w której to zagadnienie zostanie opisane wyczerpująco w ujęciu holistycznym, obejmującym jego kształt zarówno w modelu konwencyjnym, jak i w modelu przyjmowanym przez państwa niebędące członkami Rady Europy.

Tak wyznaczoną tematykę obejmują dwa kolejne rozdziały. Pierwszy z nich poświęcono analizie polskich regulacji prawnych, zaś drugi dotyczy porządku prawnego wskazanych wcześniej państw opartych na systemie prawa precedensowego. W końcowej części artykułu zaprezentowane zostały wnioski płynące z porównania przedstawionych wcześniej porządków prawnych.

\section{Habeas corpus w polskim procesie karnym}

\subsection{Uwagi ogólne}

Przystępując do analizy rozwiązań krajowych, należy rozpocząć od ustalenia treści pojęcia habeas corpus na gruncie polskiego procesu karnego, ponieważ bez uprzedniego zdefiniowania pojęcia nie sposób przejść do jego omówienia ani tym bardziej do rozstrzygnięcia, czy mechanizm ten recypowano do aktualnie obowiązującej procedury karnej.

Na potrzeby dalszych rozważań można wstępnie przyjąć, że sformułowanie to oznacza postępowanie $\mathrm{w}$ przedmiocie pozbawienia wolności, w którego toku zachowane są określone gwarancje jego rzetelności. Definicja ta nie wyjaśnia w zasadzie niczego, w związku z czym należy

15 Konwencja wiedeńska o prawie traktatów sporządzona w Wiedniu dnia 23 maja 1969 r. Dz.U. 1990, nr 74, poz. 439. 
rozważyć zakres przedmiotowy i podmiotowy tej procedury, a następnie spróbować udzielić odpowiedzi na pytanie o treść gwarancji mających zapewniać postępowaniu ową rzetelność, by w ten sposób skonkretyzować zaproponowaną definicję i przez to uczynić ją bardziej użyteczną.

\subsection{Zakres przedmiotowy i podmiotowy}

Celem wyróżniania omawianego postępowania jest określenie reguł, których przestrzeganie przez organy państwowe zagwarantuje jednostce należytą ochronę przed bezprawnym naruszaniem przysługującej jej wolności osobistej i nietykalności ${ }^{16}$. Nie powinno budzić wątpliwości, że wartości te wymagają ochrony na każdym etapie procesu karnego (choć oczywiście również i poza nim). Stąd też zakresem przedmiotowym postępowania habeas corpus należałoby objąć wszystkie formy pozbawienia jednostki wolności, w tym również na skutek orzeczenia merytorycznie kończącego sprawę i zawierającego rozstrzygnięcie o wymierzeniu oskarżonemu kary pozbawienia wolności. Równocześnie jednak - z uwagi na istnienie odrębnych (niezależnych) gwarancji, takich jak rozstrzyganie o czyjejś odpowiedzialności karnej wyłącznie przez niezależny sąd czy uprawnienie do zaskarżenia pierwszoinstancyjnego orzeczenia skazującego - rozpatrywane zagadnienie słusznie zawęża się do przypadków pozbawienia wolności w celach procesowych, tj. w inny sposób aniżeli na skutek wydania przez sąd karny orzeczenia merytorycznego.

Wydaje się, że niecelowość rozciągania gwarancji habeas corpus na wszystkie formy pozbawienia wolności dostrzega również ustrojodawca. Świadczy o tym przyznanie w art. 41 ust. 2 zdanie 1 Konstytucji RP prawa do zainicjowania niezwłocznej sądowej kontroli legalności pozbawienia wolności jedynie osobie pozbawionej jej nie na podstawie wyroku sądowego. Wynika to zapewne $\mathrm{z}$ tego, że oskarżonemu pozbawionemu wolności na podstawie wyroku sądowego (skazanemu w I instancji) podobny standard zapewniono $\mathrm{w}$ art. 176 ust. 1 Konstytucji RP (oczywiście z wyjątkiem cechy niezwłoczności kontroli, skoro, z uwagi na bezwzględną suspensywność apelacji, do faktycznej utraty wolności przez oskarżonego dojdzie dopiero na skutek ewentualnego uprawomocnienia się wyroku sądu a quo). Oznacza to, że postępowanie habeas corpus de lege lata dotyczy zatrzymania oraz tymczasowego aresztowania ${ }^{17}$. Warto zaakcentować, że procedura ta nie odnosi się wyłącznie do przypadków bezprawnego pozbawienia wolności, ponieważ to właśnie jej przebieg ma

16 Podobnie P. Kardas: Uptyw..., s. 127.

17 Ibidem, s. 121. 
dopiero doprowadzić do udzielenia odpowiedzi na pytanie o jego zasadność, legalność i prawidłowość.

Skoro zakresem przedmiotowym komentowanego trybu objęte są wszystkie przypadki zatrzymania oraz tymczasowego aresztowania, to oczywiste jest, że z kolei jego zakres podmiotowy obejmować powinien zatrzymanych i tymczasowo aresztowanych będących oskarżonymi, podejrzanymi albo osobami podejrzanymi (oskarżonymi sensu largissimo).

\subsection{Gwarancje habeas corpus}

W polskim piśmiennictwie karnoprocesowym zwraca się uwagę na kilka gwarancji procesowych, bez których - w zależności od ujęcia - o klasycznym postępowaniu habeas corpus albo w ogóle nie może być mowy, albo też funkcjonuje ono, tyle że w sposób nie całkiem prawidłowy.

Pierwszą z nich jest zagwarantowanie oskarżonemu sensu largissimo, że o legalności pozbawienia go wolności orzekać będzie wyłącznie niezależny organ sądowy. W polskim procesie karnym gwarancja ta znajduje wyraz w art. $246 \S 1$ zdanie 1 k.p.k. w odniesieniu do rozpoznania zażalenia na zatrzymanie oraz $\mathrm{w}$ art. $250 \S 1$ k.p.k. w odniesieniu do stosowania tymczasowego aresztowania. Choć dziś wydaje się to oczywiste ${ }^{18}$, jeszcze w 1996 r. (a zatem już po ratyfikowaniu przez Polskę Konwencji) o tymczasowym aresztowaniu $\mathrm{w}$ toku postępowania przygotowawczego mógł decydować prokurator ${ }^{19}$. Waga tej gwarancji nie słabnie zresztą również obecnie, kiedy wręcz na porządku dziennym są zatrzymania stosowane wyłącznie w celu spektakularnego wykazywania przez prokuraturę aktywności w ściganiu określonych osób, która to spektakularność ma niestety niewiele wspólnego z potrzebami prawidłowego postępowania ${ }^{20}$.

${ }^{18}$ Gwarancję tę samodzielnie wyróżnia Andrzej Murzynowski (A. MurzYNowski: Refleksje..., s. 8); w pracach innych autorów warunek ten wydaje się na tyle oczywisty, że wynika z innych uprawnień, takich jak prawo zatrzymanego do udziału w określonych posiedzeniach sądowych czy też do niezwłocznego przekazania go do dyspozycji sądu.

19 Zob. art. 210 Ustawy z dnia 19 kwietnia 1969 r. - Kodeks postępowania karnego (Dz.U. 1996, nr 13, poz. 96 ze zm. [Dalej: k.p.k. z 1969 r.]), w brzmieniu obowiązującym do 4 sierpnia 1996 r. Warto odnotować, że na problem ten Murzynowski zwracał uwagę na długo przed ratyfikacją Konwencji (A. MurzYNowsKi: Kilka uwag dotyczacych realizacji paktów praw człowieka $w$ polskim prawie karnym procesowym. „Acta Universitatis Wratislaviensis. Prawo" 1990, t. 173, s. 71-72); por. E. SKRĘTOwICZ: Kodeks postępowania karnego. Wprowadzenie. Kraków 1996, s. 10-11, za: A. MurzYNowsKi: Refleksje..., s. 9; zob. również: Wyrok ETPCz z 4 lipca 2000 r. w sprawie Niedbała przeciwko Polsce. Skarga nr 27915/95, § 49. www.echr.coe.int.

20 Tak trafnie J. SKoruPKa: Zatrzymanie procesowe osoby podejrzanej. „Prokuratura i Prawo" 2007, nr 11, s. 24; S. Waltoś, P. Hofmański: Proces karny..., s. 411 [przyp. 5]. 
Zakresem omawianego standardu nie objęto nigdy etapu samego wydawania decyzji o zatrzymaniu. Czynność ta w sposób oczywisty wpisana jest w procesową funkcję ścigania, a przy tym dla swej skuteczności wymaga możliwie szybkich i niesformalizowanych działań, w związku z czym dla niezależnego organu sądowego słusznie zastrzega się „dopiero” etap kontroli legalności dokonanego już zatrzymania.

Kolejną gwarancją jest niezwłoczność przekazania zatrzymanego do dyspozycji sądu. W polskim porządku prawnym ma ją zapewniać art. 41 ust. 3 zdanie 2 i 3 Konstytucji RP oraz rozwijająca go regulacja art. 248 k.p.k., w myśl których jednostkę należy przekazać do dyspozycji sądu najpóźniej w ciągu 48 godzin od chwili zatrzymania, a następnie zwolnić, jeżeli w ciągu 24 godzin od przekazania jednostki do sądu nie doręczono jej postanowienia o zastosowaniu tymczasowego aresztowania wraz z przedstawionymi zarzutami. Poza tym należy ją zwolnić natychmiast, jeżeli - choćby nawet przed upływem zakreślonych terminów - ustały przyczyny zatrzymania. Warto zauważyć, że jest to unormowanie wyjątkowo precyzyjne jak na akt rangi konstytucyjnej, w związku z czym nie powinno budzić wątpliwości, że ustawodawca nie może wprowadzać względem niego jakichkolwiek wyjątków ${ }^{21}$. Tę gwarancyjną funkcję dodatkowo wzmacnia sposób interpretacji zaproponowany w literaturze, zgodnie z którym upływ wskazanych terminów oznacza nie tylko obowiązek wypuszczenia zatrzymanego, ale również konieczność umorzenia toczącego się postępowania w przedmiocie zastosowania tymczasowego aresztowania ${ }^{22}$. Jak bowiem argumentował Piotr Kardas: „[...] przewidziane $\mathrm{w}$ art. 41 ust. 3 Konstytucji [...] przesłanki wydania rozstrzygnięcia $\mathrm{w}$ przedmiocie oceny legalności pozbawienia wolności pro futuro określają nieprzekraczalne ramy, w jakich możliwe jest wydanie postanowienia $\mathrm{w}$ przedmiocie tymczasowego aresztowania $\mathrm{w}$ ramach postępowania incydentalnego zainicjowanego wnioskiem o tymczasowe aresztowanie składanym w wyniku uprzedniego zatrzymania. [...] Po upływie tego terminu wydanie postanowienia w przedmiocie tymczasowego aresztowania $\mathrm{w}$ ramach tego postępowania incydentalnego nie jest prawnie możliwe"23. Na ścisły związek czasowy pomiędzy zatrzymaniem

${ }^{21}$ P. Kardas: Upływ..., s. 134; zob. jednak art. 248 § 2 in fine k.p.k., w którym odstąpiono od konstytucyjnego wymogu doręczenia zatrzymanemu postanowienia o zastosowaniu tymczasowego aresztowania, uznając za wystarczające w wypadku wskazanym $\mathrm{w}$ art. 250 § 3b k.p.k. poprzestanie na jego ogłoszeniu; regulację tę należy uznać za oczywiście sprzeczną z art. 41 ust. 3 zdanie 3 Konstytucji RP.

22 P. KaRdas: Uptyw..., s. 121-122.

${ }^{23}$ Ibidem, s. 131. Równocześnie autor zastrzega, że w stosunku do tej samej osoby w dalszym ciągu może być stosowane tymczasowe aresztowanie na potrzeby tego samego postępowania, z tym jednak, że musi być ono oparte na innym wniosku prokuratora (s. 140). 
a tymczasowym aresztowaniem wskazuje również art. 265 k.p.k., zgodnie z którym okres tymczasowego aresztowania należy liczyć od dnia zatrzymania.

$\mathrm{Za}$ jedną z najbardziej problematycznych wśród wyróżnianych gwarancji habeas corpus należy uznać automatyczny charakter sądowej kontroli zatrzymania, rozumiany jako jej uniezależnienie od złożenia stosownego wniosku przez osobę pozbawioną wolności ${ }^{24}$. Standard ten wywodzi się m.in. z art. 5 ust. 3 EKPCz, wskazując, że wyrażone w ust. 4 tego przepisu uprawnienie do „odwołania się do sądu w celu ustalenia bezzwłocznie przez sąd legalności pozbawienia wolności i zarządzenia zwolnienia, jeżeli pozbawienie wolności jest niezgodne z prawem" stanowi - pojęciowo i funkcjonalnie - zupełnie odrębne uprawnienie $^{25}$. Przyjmuje się, że ów automatyzm kontroli sądowej pełni szczególnie istotną rolę wówczas, gdy osoba pozbawiona wolności nie byłaby w stanie sama złożyć stosownego wniosku (np. na skutek bezprawnego traktowania jej przez funkcjonariuszy państwa, określonych zaburzeń psychicznych czy nieznajomości języka) ${ }^{26}$. W piśmiennictwie niekiedy wskazuje się, że ustawodawca nie spełnia w tym względzie standardu strasburskiego, skoro sądowa kontrola legalności zatrzymania uzależniona jest od złożenia przez zatrzymanego zażalenia w trybie art. $246 \S 1$ k.p.k. ${ }^{27}$. W myśl przeciwnego, zdecydowanie mniej gwarancyjnego poglądu, wyrażonego przez ETPCz m.in. w sprawie Brogan, „do naruszenia art. 5 ust. 3 [EKPCz - B.Ł.] nie dochodzi wówczas, gdy przed upływem

24 Zob. J. SKoruPKa: Zatrzymanie..., s. 30.

${ }^{25}$ Szerzej zob. M.A. Nowicki: Wokót Konwencji Europejskiej. Krótki komentarz do Europejskiej Konwencji Praw Człowieka. Warszawa 2006, s. 138-145 i przywołane tam orzecznictwo ETPCz.

${ }^{26}$ Tak trafnie P. Hofmański, w: Konwencja o Ochronie Praw Człowieka i Podstawowych Wolności. T. 1: Komentarz do artykułów 1-18. Red. L. GARLICKI. Warszawa 2010 [nb. 105 do art. 5], z powołaniem się na: Wyrok ETPCz z 3 października 2006 r. w sprawie McKay przeciwko Zjednoczonemu Królestwu. Skarga nr 543/03, § 34. www.echr.coe.int; Wyrok ETPCz z 18 marca 2008 r. w sprawie Ladent przeciwko Polsce. Skarga 11036/03, § 74. www.echr.coe.int.

27 Tak trafnie J. SкоRUPка: Zatrzymanie..., s. 30-31. Zdaniem Piotra Kardasa do sądowej kontroli legalności zatrzymania może dojść również z urzędu, pomimo niewniesienia przez zatrzymanego zażalenia, w przypadku skierowania przez prokuratora wniosku o zastosowanie tymczasowego aresztowania (P. KARDAs: Uptyw..., s. 131). Odmienne stanowisko zajmuje Jerzy Skorupka, który wskazuje, że w razie złożenia takiego wniosku sąd aresztowy nie będzie oceniał zasadności pozbawienia wolności wstecz (zatrzymanie), a jedynie dopuszczalność pozbawienia wolności na przyszłość (tymczasowe aresztowanie) (J. SKоRUPKa: Granice ingerencji $w$ wolność osobista jednostki i prawo do nieobciażania się $w$ postępowaniu karnym. W: Model dopuszczalnej ingerencji $w$ prawa $i$ wolności jednostki $w$ procesie karnym - The model of acceptable interference with the rights and freedoms of an individual in the criminal process. Red. J. SKоRUPKA. Warszawa 2019, s. 207). 
terminu niezwłoczności « osoba zatrzymana zostanie zwolniona”, byleby ustawodawca zapewnił jej możliwość skorzystania z przewidzianego $\mathrm{w}$ art. 5 ust. 4 EKPCz uprawnienia do zainicjowania następczej kontroli odwoławczej $^{28}$.

Za element postępowania habeas corpus uznaje się również przyznanie zatrzymanemu uprawnienia do udziału w posiedzeniu sądu rozpoznającego zażalenie na zatrzymanie ${ }^{29}$. W polskiej procedurze karnej wynika ono z art. 464 § 1 k.p.k. Opisywany udział trzeba rozumieć dosłownie, w związku z czym za niewystarczającą należy uznać obecność samego obrońcy lub pełnomocnika (choć oczywiście także oni powinni być dopuszczeni do udziału w posiedzeniu). Zdaniem Jerzego Skorupki: „Począwszy od wyroku w sprawie Nikolova przeciwko Bułgarii, ETPCz uznaje, że w razie pozbawienia wolności na podstawie art. 5 ust. 1 lit. c Konwencji, konieczne jest bezpośrednie, osobiste wysłuchanie (hearing) osoby pozbawionej wolności przez sąd" ${ }^{30}$. Gwarancję tę należy rozciągnąć również na wszelkie inne posiedzenia dotyczące pozbawienia wolności oskarżonego sensu largissimo. Obecnie przysługuje mu ona $\mathrm{w}$ odniesieniu do posiedzenia mającego za przedmiot zastosowanie tymczasowego aresztowania (arg. ex art. 249 § 3 zdanie 1 k.p.k.), jednak już w przypadku posiedzenia dotyczącego przedłużenia stosowania tego środka zapobiegawczego albo rozpoznania zażalenia na jego zastosowanie lub przedłużenie, w myśl art. 249 § 5 zdanie 1 k.p.k., wystarczająca jest obecność obrońcy i prokuratora. Oznacza to, że w tym ostatnim przypadku przysługujące tymczasowo aresztowanemu prawo do obrony zostało ograniczone do aspektu formalnego. Różnica ta wynika zapewne z przyjęcia przez ustawodawcę założenia, że wystarczające jest, aby sąd jednokrotnie zetknął się z zatrzymanym lub tymczasowo aresztowanym osobiście. W wypadku zatrzymania kontakt ten ma miejsce dopiero na etapie postępowania zażaleniowego. $\mathrm{Z}$ kolei tymczasowe aresztowanie stosowane jest de lege lata jedynie przez sąd, w związku z czym uznano, że nie istnieje potrzeba ponownego sprowadzania podejrzanego czy oskarżonego na posiedzenie dotyczące rozpoznania zażalenia na zastosowanie lub przedłużenie stosowania tego środka. Rozwiązanie to, uzasadnione jedynie względami ekonomii procesowej, prowadzi do bezzasadnego pozbawienia jednostki gwarancji

28 Tak P. Hofmański, w: Konwencja o Ochronie Praw Człowieka i Podstawowych Wolności. T. 1: Komentarz... [nb. 107 do art. 5]; Wyrok ETPCz z 29 listopada 1988 r. w sprawie Brogan i in. przeciwko Zjednoczonemu Królestwu. Seria A nr 145-B, § 58; zob. również P. Hofmański: Europejskie..., s. 454.

29 S. Waltoś, P. Hofmański: Proces karny..., s. 414-415.

30 J. SKorupKa: Zatrzymanie..., s. 29; Wyrok ETPCz z 25 marca 1999 r. w sprawie Nikolova przeciwko Bułgarii. Skarga nr 31195/96, § 58. www.echr.coe.int. 
konstytucyjnych, o których mowa w art. 42 ust. 2 zdanie 1 oraz art. 45 ust. 1 Konstytucji $\mathrm{RP}^{31}$.

Ostatnią z powszechnie wyróżnianych gwarancji stanowiących trzon postępowania habeas corpus jest zasada równości broni (equality of arms). Przyjmuje się, że procedura tego typu powinna się opierać na elementach kontradyktoryjności, zapewniając w ten sposób stronom m.in. równe możliwości zaprezentowania swoich argumentó $\mathrm{w}^{32}$. Jednym $\mathrm{z}$ aspektów tej gwarancji jest zapewnienie równego dostępu do akt sprawy, na tle której doszło do zatrzymania lub tymczasowego aresztowania, co ma umożliwić zatrzymanemu lub tymczasowo aresztowanemu skuteczne podważenie argumentów przemawiających za stosowaniem tych środków przymusu. Oskarżony sensu largissimo powinien mieć zatem świadomość istnienia dowodów dla niego niekorzystnych, a co ważniejsze - możliwość odniesienia się do nich ${ }^{33}$. Standardu tego nie gwarantuje ustawa procesowa w jej aktualnym brzmieniu. Począwszy od 15 kwietnia 2016 r., zgodnie z art. 249 a $\$ 1$ pkt 2 k.p.k., postanowienie o zastosowaniu lub przedłużeniu tymczasowego aresztowania może się opierać na ustaleniach poczynionych na podstawie dowodów z zeznań świadka, o którym mowa w art. 250 § 2 b k.p.k., niejawnych zarówno dla samego tymczasowo aresztowanego, jak i dla jego obrońcy. Tymczasem, jak trafnie przyjmuje się w orzecznictwie ETPCz, jakkolwiek z potrzeby zagwarantowania przeprowadzenia skutecznego śledztwa może wynikać konieczność utrzymania w tajemnicy części zebranych w jego toku informacji, w celu zapobieżenia bezprawnemu zakłócaniu przez podejrzanych przebiegu procesu, to jednak ów - słuszny skądinąd - cel nie może być osiągany kosztem istotnych ograniczeń prawa do obrony ${ }^{34}$. Skorupka stoi na stanowisku,

31 Tak również J. SкоRupKa, w: Kodeks postępowania karnego. Komentarz. Red. J. SKoruPKa. Warszawa 2020, s. 610.

32 M. WĄSEK-WIADEREK: Dostęp do akt sprawy oskarżonego tymczasowo aresztowanego i jego obrońcy w postępowaniu przygotowawczym - standard europejski a prawo polskie. „Palestra” 2003, nr 3-4, s. 56; P. KARDAs: Standard rzetelnego procesu a prawo wgladu do akt sprawy $w$ postępowaniu $w$ przedmiocie tymczasowego aresztowania, czyli historia jednej nowelizacji. „Prokuratura i Prawo” 2010, nr 1-2, s. 92; Wyrok ETPCz z 25 czerwca 2002 r. w sprawie Migoń przeciwko Polsce. Skarga nr 24244/94, § 68. Legalis.

${ }_{33}$ M. WĄSEK-WiadereK: Dostęp do akt..., s. 56; P. KARDAS: Standard..., s. 92; J. SKORUPKA: $W$ kwestii dostępu tymczasowo aresztowanego do wniosku $w$ przedmiocie tymczasowego aresztowania oraz do akt sprawy $w$ postępowaniu przygotowawczym na marginesie orzeczeń sądów powszechnych. „Palestra” 2008, nr 7-8, s. 47-49; IDEM: Udostępnienie akt sprawy podejrzanemu. „Prokuratura i Prawo” 2007, nr 5, s. 71; por. P. WiLIŃski: Odmowa dostępu do akt sprawy w postępowaniu przygotowawczym: „Prokuratura i Prawo” 2006, nr 11, s. $74-85$.

${ }^{34}$ Zob. P. Kardas: Standard..., s. 92 i cytowane tam orzecznictwo ETPCz; por. Wyrok Trybunału Konstytucyjnego z dnia 3 marca 2008 r. K 42/07, OTK-A 2008, nr 5, poz. 77 z częściowo aprobującymi uwagami Piotra Kardasa i Pawła Wilińskiego (P. Kardas, 
że ze wskazanych powodów przywołany przepis jest sprzeczny z postanowieniami Dyrektywy Parlamentu Europejskiego i Rady 2012/13/UE z dnia 22 maja 2012 r. w sprawie prawa do informacji w postępowaniu karnym $^{35}$.

\subsection{Podsumowanie}

Omówione uprawnienia nie wyczerpują zbioru gwarancji immanentnie związanych ze standardem habeas corpus, stanowiąc co najwyżej ich użyteczną egzemplifikację. Standard ten należałoby uzupełnić chociażby o prawo do otrzymania wyczerpującego uzasadnienia decyzji skutkującej pozbawieniem jednostki wolności, w którego treści organ szczegółowo wyjaśni przyczyny oraz konieczność zastosowania danego środka przymusu (zob. art. $251 \S 3$ k.p.k.).

Katalogu gwarancji tej procedury nie powinno się postrzegać jako statycznego. Ich zakres, warunkujący uznanie postępowania w przedmiocie pozbawienia wolności za „dostatecznie rzetelne”, nie jest ustalony raz na zawsze, ale zmienny w czasie, zależny od systemu wartości i ocen wyrażanych przez społeczeństwo na danym etapie rozwoju cywilizacyjnego. Standard ten ewoluuje, tak jak w orzecznictwie Europejskiego Trybunału Praw Człowieka ewoluuje samo pojęcie rzetelności i rzetelnego postępowania $^{36}$. Przykładowo, o ile dawniej obowiązek postawienia zatrzymanego przed sędzią i umożliwienia mu udziału w posiedzeniu sądu bez wątpienia rozumiany był jako zagwarantowanie oskarżonemu sensu largissimo osobistej (fizycznej) styczności z sądem, o tyle obecnie - właśnie w związku z rozwojem społecznym oraz technologicznym - zasadniczych wątpliwości co do rzetelności nie budzi przewidziana $\mathrm{w}$ postępowaniu przyspieszonym możliwość odstąpienia od doprowadzenia jednostki do sądu, a zapewnienia jej uczestnictwa we wszystkich czynnościach sądowych przy

P. WilińsKi: O niekonstytucyjności odmowy dostępu do akt sprawy w postępowaniu $w$ przedmiocie tymczasowego aresztowania. „Palestra” 2008, nr 7-8, s. 23-35); Postanowienie Trybunału Konstytucyjnego z dnia 27 stycznia 2004 r. SK 50/03, OTK-A 2004, nr 1, poz. 6.

35 Dyrektywa Parlamentu Europejskiego i Rady 2012/13/UE z dnia 22 maja 2012 r. w sprawie prawa do informacji w postępowaniu karnym. Dz.Urz. UE L nr 142, s. 1; J. SKorupKa, w: Kodeks postępowania karnego. Komentarz..., s. 611; IDEM: Access to detainees' files in the light of Directive 2012/13/EU of the European Parliament and of the Council of 22 May 2012 on the right to information in criminal proceedings and under Polish law. „Ius Novum” 2017, no. 2, s. 136-137.

${ }^{36}$ P. Hofmański, A. Wróbel, w: Konwencja o Ochronie Praw Człowieka i Podstawowych Wolności. T. 1: Komentarz do artykułów 1-18. Red. L. GARLICKI. Warszawa 2010 [nb. 161 do art. 6]. 
użyciu urządzeń technicznych, umożliwiających przeprowadzenie tych czynności na odległość z jednoczesnym bezpośrednim przekazem obrazu i dźwięku (zob. art. 517b § 2a k.p.k.). Co więcej, na skutek trwającej pandemii COVID-19 rozszerzono możliwość zdalnego udziału w posiedzeniu aresztowym również na wszelkie inne rodzaje postępowań, przy czym rozwiązanie to ma $\mathrm{w}$ założeniu pozostać elementem polskiego procesu karnego także po ostatecznym ustaniu pandemii (zob. art. $250 \S 3 \mathrm{~b}-3 \mathrm{~h}$ k.p.k.). Innymi słowy, bez względu na swoistą podatność poszczególnych gwarancji wchodzących w skład omawianego standardu na zmienność otaczającej rzeczywistości, ważne jest, aby za rzetelne można było uznać konkretne postępowanie oceniane jako całość. Próbując zatem uzupełnić zaproponowaną wcześniej definicję o poczynione ustalenia, należy przyjąć, że postępowanie habeas corpus to postępowanie w przedmiocie pozbawienia oskarżonego sensu largissimo wolności dla celów procesowych, w którego toku zachowane są uprawnienia uznawane w danym czasie za gwarantujące łącznie jego rzetelność.

Wydaje się, że rodzime postępowania $\mathrm{w}$ przedmiocie pozbawienia wolności na skutek zatrzymania lub tymczasowego aresztowania nie wpisują się $\mathrm{w}$ tak sformułowaną definicję. Wskazany brak gwarancji udziału oskarżonego sensu largissimo $\mathrm{w}$ toku posiedzeń sądowych dotyczących przecież jego wolności, a także rażąca wręcz nierówność stron w zakresie dostępu do akt sprawy nie pozwalają uznać tego typu procedur za „dostatecznie rzetelne” ${ }^{37}$. Wątpliwości budzi też umożliwienie organom państwa przetrzymywania zatrzymanego bez zgody sądu aż przez 72 godziny. Dostępne obecnie środki techniczne pozwalają powątpiewać $\mathrm{w}$ to, że na ocenę legalności zatrzymania rzeczywiście potrzebne są aż 3 pełne doby (por. art. 207 k.p.k. z 1969 r.). Oceny tej nie może zmieniać fakt, że postępowania $\mathrm{w}$ dużej części spełniają standard habeas corpus, tj. w ich toku przewiduje się gwarancje składające się na ów standard. Istotne jest bowiem jedynie to, że nie spełniają go przynajmniej w jakiejś części, przez co stają się nierzetelne nie w części, ale w całości.

37 Podobnie W. Hermeliński, B. NitA-ŚwiatŁowsKa: Kilka uwag o prawie do obrony w związu z nowelizacja Kodeksu postępowania karnego z 2016 roku. „Palestra” 2016, nr 9, s. 24, z powołaniem się na: Wyrok ETPCz z 26 listopada 2013 r. w sprawie Emilian-George Igna przeciwko Rumunii, 26 listopada 2013 r. Skarga nr 21249/05, § 31-33. www.echr.coe.int. 


\section{Habeas corpus w systemie common law}

\subsection{Uwagi ogólne}

Należy rozpocząć od zwrócenia uwagi, że w państwach kręgu common law, inaczej niż w polskiej nauce karnoprocesowej, mówi się nie tyle o postępowaniu habeas corpus (perspektywa procesowa), ile raczej o zasadzie (instytucji) habeas corpus (perspektywa materialnoprawna). Optyka ta została przyjęta również na potrzeby tej części opracowania, ze wszystkimi tego konsekwencjami.

Powszechnie wskazuje się na dwa źródła omawianej zasady (przywileju), tj. na wydany w 1166 r. przez Henryka II Plantageneta akt Assize of Clarendon oraz na promulgowaną w $1215 \mathrm{r}$. przez Jana bez Ziemi Wielką Kartę Swobód ${ }^{38}$. Zgodnie z art. 36 drugiego z tych aktów: „Żaden wolny człowiek nie może być aresztowany ani uwięziony, albo pozbawiony mienia, wyjęty spod prawa, wygnany lub w jakikolwiek sposób ciemiężony i nie wyprawimy się przeciwko niemu ani nikogo przeciwko niemu nie wyślemy inaczej jak tylko na podstawie prawomocnego wyroku równych mu lub z mocy prawa krajowego" 39 . Zasadę mówiącą o konieczności zbadania przez sąd legalności zatrzymania jednostki znacząco umocnił w 1679 r. Habeas Corpus Act. W XIII w. z pewnością nie można było przewidywać, że wspomniany, wynikający z Magna Charta Libertatum przywilej po ponad 800 latach nadal stanowić będzie fundament systemu prawa common law, ani tym bardziej, że będzie promieniował na inne porządki prawne. $\mathrm{Z}$ uwagi na terytorialną ekspansję imperium angielskiego (a później brytyjskiego), jak również swoisty kolektywizm systemów prawa, omawiana gwarancja ma obecnie znaczenie niemal globalne.

$\mathrm{W}$ piśmiennictwie wskazuje się, że uprawnienia wynikające z zasady habeas corpus aktualnie mają charakter praw człowieka. W zależności od ujęcia uznaje się je za stanowiące element prawa do sądu lub prawa do rzetelnego procesu ${ }^{40}$. Prawa te są immanentnie związane $\mathrm{z}$ samą istotą człowieczeństwa, w literaturze prawniczej nazywaną zwykle przyrodzoną godnością. Rację miał zatem William Blackstone, wskazując, że habeas corpus jest jednym z otoczonych największą estymą zwyczajów całego systemu common law. Przyjmował, że do podstawowych praw człowie-

38 Szerzej zob.: English historical documents. Vol. 2: 1042-1189. Eds. D.C. DougLaS, G.W. GREENAWAY. London 1981, s. 440-443; N.D. HuRNARD: The jury of presentment and the Assize of Clarendon. „The English Historical Review” 1941, no. 56, s. 374-410 i cytowana tam literatura.

39 I. JAwORSKI: Zarys powszechnej historii państwa i prawa. Warszawa 1978, s. 136.

40 Por. K. SójKA-ZielińsKA: Cesare Beccaria a ochrona praw człowieka w procesie karnym. „Analecta. Studia i Materiały z Dziejów Nauki” 1995, z. 2, s. 29-30. 
ka należą prawo do ochrony bezpieczeństwa i wolności oraz prawo do ochrony posiadania, zaś realizacja omawianego przywileju miała służyć niejako ochronie obu tych gwarancji ${ }^{41}$.

\subsection{Zakres podmiotowy i przedmiotowy}

W swoim oryginalnym, XIII-wiecznym znaczeniu, instytucja habeas corpus miała chronić przed autorytaryzmem monarchy jedynie parów (podobnie zresztą jak rodzima formuła neminem captivabimus nisi iure victum miała zabezpieczać wyłącznie interesy szlachty). Obecnie odnosi się ona rzecz jasna do ogółu ludności przebywającej na terytorium danego państwa. W XVIII w. jej zakresem podmiotowym objęto każdego, kto został pozbawiony wolności. Na oskarżycielu (zarządcy lub naczelniku więzienia) spoczywał obowiązek udowodnienia przed sądem, na żądanie pozbawionego wolności, że jego zatrzymanie było konieczne, a przy tym zgodne z prawem. Konieczne było również wykazanie istnienia materiału dowodowego, który wystarczająco uzasadniał zatrzymanie ${ }^{42}$. Rdzeń tej zasady zasadniczo nie zmieniał się i uprawnienie wypływające z komentowanej zasady w dalszym ciągu przyznawane jest ex lege wszystkim, którzy zostali pozbawieni wolności. Warto jednak zauważyć, że kontrola zatrzymania nie ma charakteru samowykonalnego (self-executing). Inicjowana jest przez osobę pozbawioną wolności, która w tym celu musi wystąpić przeciwko naczelnikowi albo zarządcy więzienia z pozwem, w którym podważy legalność zatrzymania. Oznacza to, że w systemie prawa angielskiego analizowana procedura oparta jest na rozwiązaniach cywilnoprawnych. Znane z polskiego porządku prawnego zażalenie na zatrzymanie przybiera tam więc postać pozwu kierowanego przeciwko konkretnej osobie sprawującej władzę w imieniu państwa. Po jego przyjęciu do rozpoznania właściwy sąd wystawia tzw. writ of habeas corpus, tj. nakaz dostarczenia osoby zatrzymanej przed oblicze sądu ${ }^{43}$, co rozpoczyna postępowanie w sprawie zastosowania omawianego przywileju. W jego trakcie sąd nie orzeka merytorycznie, tzn. nie rozstrzyga o sprawstwie czy winie domniemanego sprawcy, badając jedynie legalność jego zatrzymania. Jak

${ }^{41}$ W. BLackstone: Commentaries on the laws of England. A facsimile of the first edition of 1765-1769. Vol. 1. Chicago 1979, s. 125.

${ }^{42}$ Ibidem.

${ }^{43}$ Zob. art. 10 ust. c Kanadyjskiej Karty Praw i Swobód (zob. A consolidation of the constitution acts - Codification administrativedes lois constitutionnelles. https://laws -lois.justice.gc.ca/eng/Const/page-15.html [dostęp: 24.11.2020]) oraz art. 1 § 9 zdanie 2 Konstytucji USA (Konstytucja Stanów Zjednoczonych Ameryki. http://libr.sejm.gov.pl/ tek01/txt/konst/usa.html [dostęp: 24.11.2020]). 
trafnie zauważył John Marshall, prezes Sądu Najwyższego USA w latach 1801-1835, celem tego postępowania jest uniemożliwienie pozbawienia jednostki wolności bez wystarczającego powodu ${ }^{44}$.

Warto podkreślić, że w krajach systemu common law omawiany tryb nie ogranicza się wyłącznie do postępowania karnego sensu stricto. Dotyczy każdego, kto został pozbawiony wolności na podstawie prawa (stąd też oczywiście nie obejmuje przypadków bezprawnego pozbawienia wolności przez inną osobę fizyczną). Chodzi tu zatem również o inkarcerację w związku z procedurą ekstradycyjną czy przymusową izolację wynikającą z konieczności poddania się określonemu leczeniu ${ }^{45}$. Wskazuje się nawet na zastosowanie omawianego przywileju $\mathrm{w}$ postępowaniach $\mathrm{z}$ zakresu prawa imigracyjnego ${ }^{46}$.

Należy zaakcentować, że postępowanie wszczynane na mocy wniosku (petition) o wydanie writ of habeas corpus nie jest postępowaniem odwoławczym, co na gruncie prawa omawianej grupy państw bynajmniej nie jest tak oczywiste ${ }^{47}$. Uprawnienie do wniesienia apelacji dotyczy wyroków o charakterze merytorycznym, podczas gdy swoisty zarzut habeas corpus przysługuje $\mathrm{w}$ razie pozbawienia wolności in genere. Jego celem jest zbadanie legalności zatrzymania, które może mieć miejsce zarówno przed, jak i po wydaniu wyroku. Różnice pomiędzy obydwoma trybami są więc zasadnicze. W zakresie realizacji uprawnienia wynikającego z omawianej zasady w toku postępowania przygotowawczego sąd wprawdzie dokonuje rewizji siły zarzutów postawionych jednostce, jednak wyłącznie w celu rozstrzygnięcia kwestii legalności zatrzymania, ewentualnie - $\mathrm{w}$ razie uznania go za legalne - orzeczenia w przedmiocie tymczasowego aresztowania w oczekiwaniu na proces. Alternatywą jest w tym przypadku zwolnienie $\mathrm{z}$ aresztu za kaucją (realease on bail). Jednostka osadzona na mocy wyroku sądu I instancji może zwrócić się o wydanie writ of habeas corpus także w trakcie postępowania apelacyjnego, wskazując na błędy formalnoprawne popełnione $\mathrm{w}$ postępowaniu przygotowawczym lub pierwszoinstancyjnym, jeżeli mogły one mieć znaczenie dla oceny legalności pozbawienia wolności (np. zebranie materiału dowodowego w niewłaściwy

${ }_{44}$ W.S. Снurch: A treatise of the writ of habeas corpus. Including jurisdiction, false imprisonment, writ of error, extradition, mandamus, certiorari, judgments, etc. With practice and forms. San Francisco 1886, s. 279.

45 Szerzej zob.: R.J. Sharpe: Habeas corpus, extradition and the burden of proof: The case of the man who escaped from Devil's Island. „The Cambridge Law Journal” 1990, no. 3, s. 422-440; W. BlackstonE: Commentaries on the laws of England..., s. 131; D. PARKs: The "great writ" reinvigorated? Habeas corpus in contemporary Canada. „Manitoba Law Journal" 2012, no. 1, s. 352.

${ }^{46}$ R.J. Sharpe: Habeas corpus in Canada. „Dalhousie Law Journal” 1975, no. 2, s. 247.

47 R.V. Del Carmen: Criminal procedure. Law and practice. Belmont 2007, s. 65. 
sposób). W zależności od mocy takich zarzutów sąd orzeka w przedmiocie zwolnienia $\mathrm{z}$ odbywania kary ${ }^{48}$. Tymczasem $\mathrm{w}$ toku rozpoznawania apelacji sąd II instancji obowiązany jest do zbadania całokształtu sprawy z punktu widzenia zarówno formalno-, jak i materialnoprawnego (oczywiście $\mathrm{z}$ uwzględnieniem funkcjonujących $\mathrm{w}$ danym państwie reguł wyznaczających granice kontroli odwoławczej). Uruchomienie postępowania apelacyjnego nie jest możliwe bez uprzedniego wydania w sprawie orzeczenia o charakterze merytorycznym, podczas gdy procedura dotycząca analizowanego przywileju może być wszczęta zarówno przed, jak i po wydaniu wyroku.

Instytucja habeas corpus powiązania jest również z pozbawieniem wolności na skutek tymczasowego aresztowania (remand in detention lub pre-trial detention). Przesłanki stosowania tego środka w omawianych państwach są co do zasady zbieżne $\mathrm{z}$ rozwiązaniami polskimi, w związku z czym nie ma potrzeby ich dodatkowego omawiania. Na marginesie warto zauważyć, że podobieństwo to nie wynika z przenikania elementów systemu prawa kontynentalnego na grunt systemu common law lub odwrotnie, ale spowodowane jest internacjonalizacją standardów związanych z ochroną jednostki przed niesłusznym pozbawieniem wolności ${ }^{49}$.

Podsumowując, przywilej habeas corpus rozumiany jest przede wszystkim jako zasada (instytucja) anglosaskiego procesu karnego, mająca na celu ochronę oskarżonego sensu largissimo przed pozbawieniem wolności niezwiązanym $\mathrm{z}$ wydaniem $\mathrm{w}$ jego sprawie prawomocnego orzeczenia merytorycznego. Pojęcie habeas corpus może być przy tym rozumiane dwojako. Po pierwsze, jako rodzaj nakazu sądowego (the writ of habeas corpus), oznaczającego żądanie dostarczenia „ciała” (corpus), tj. jako zawezwanie do postawienia oskarżonego sensu largissimo przed niezależnym sądem, który oceni wagę dowodów zebranych przeciwko niemu oraz oceni legalność jego zatrzymania. Dokument ten przybiera zwykle następującą treść: „My, jako Sąd, rozkazujemy Ci, żebyś sprowadził osobę zatrzymaną przed nasze oblicze” (oryg. „We, a Court, command that you have a body of the detainee brought before us" ${ }^{50}$ ). Po drugie, jako standard procesowy

${ }^{48}$ Wskazuje się, że do skutecznego wszczęcia procedury habeas corpus na etapie postępowania przed sądem II instancji dochodzi niezwykle rzadko. Niekiedy podnosi się, że tryb ten mógłby stanowić przejaw powtórnego rozpatrywania tej samej sprawy. Równocześnie jednak trafnie dostrzeżono, że w zakres kognicji sądu orzekającego w procedurze habeas corpus, mającej charakter jedynie poboczny względem postępowania głównego, nie wchodzą materialnoprawne aspekty sprawy, przez co nie dochodzi do naruszenia reguły ne bis in idem (zob. ibidem, s. 65).

49 Szerzej zob.: J. Dressler, G.C. Thomas III: Criminal procedure. Prosecuting crime. St. Paul 2006, s. 786; R.V. DEL CARMEN: Criminal procedure..., s. 175-176.

${ }^{50}$ Habeas corpus. Legal Information Institute. https://www.law.cornell.edu/wex/habeas_corpus [dostęp: 18.08.2021] (tłum. - P.K.). 
chroniący jednostkę przed wszechwładztwem ze strony państwa - aspekt ten został omówiony $\mathrm{w}$ dalszej części opracowania. Przywilej habeas corpus może być inwokowany przez każdą osobę pozbawioną wolności $\mathrm{w}$ świetle prawa (color of law ${ }^{51}$ ). W razie uznania, że zatrzymanie było niezgodne $\mathrm{z}$ prawem, sąd nakazuje zarządcy lub naczelnikowi więzienia natychmiastowe zwolnienie zatrzymanego ${ }^{52}$. Instytucja ta może być więc wykorzystana w celu zbadania legalności pozbawienia wolności ad hoc, bez konieczności rozstrzygania kwestii stricte merytorycznych ${ }^{53}$.

\subsection{Gwarancje habeas corpus}

W anglosaskiej literaturze podnosi się, że zasada habeas corpus ma przede wszystkim charakter gwarancyjny, ponieważ służy ochronie podstawowego prawa człowieka - prawa do wolności. Należy ją postrzegać w pierwszej kolejności jako wyrażającą konieczność zbadania przez niezależny organ prawidłowości i legalności zatrzymania. Jak trafnie podkreślał William Blackstone, to właśnie niezależny sąd powinien orzekać, czy pozbawionego wolności należy zwolnić, zwolnić za kaucją czy może tymczasowo aresztowaćs ${ }^{54}$ W myśl tej reguły pozbawienie wolności powinno mieć zawsze charakter wyjątkowy, w związku z czym rozstrzyganie $\mathrm{w}$ tym przedmiocie powinno leżeć $\mathrm{w}$ kompetencji niezależnego organu, który będzie z jednej strony stał na straży interesu publicznego, a z drugiej bronił interesu prywatnego jednostki. Organem takim jest niezależny sąd i sędzia.

Równie istotną kwestią jest niezwłoczność postawienia osoby zatrzymanej przed sądem, ponieważ w sytuacji pozostawania jednostki pod kontrolą organów ścigania może się pojawić pokusa zastosowania wobec niej tzw. aresztu wydobywczego. W celu ochrony przed tym zjawiskiem państwa zazwyczaj nakładają pewne czasowe ograniczenia zatrzymania (limity), immanentnie związane z prawem do przeprowadzenia procesu

51 Zob. S.H. GIFIs: Law dictionary. New York 1996, s. 86. Por. również znane z amerykańskiego języka prawnego i prawniczego określenie under authority of law, na język polski (choć niezbyt precyzyjnie) tłumaczone zwykle jako „w świetle prawa” lub „zgodnie z prawem", choć w USA używane raczej wyłącznie w odniesieniu do czynów dokonywanych przez osoby pełniące funkcję oficjalną, powiązaną z wykonywaniem władzy państwowej, kiedy konieczne jest powołanie się na taką funkcję w celu legitymizacji przedsiębranych zachowań (Judicial and statutory definitions of words and phrases. St. Paul 1914, s. 763).

${ }^{52}$ H. Wajs: Habeas Corpus Act z 1679 roku. W: Ksiega jubileuszowa Rzecznika Praw Obywatelskich. T. 1: Pomniki praw człowieka $w$ historii. Red. H. WaJs, R. WiткоwsкI. Warszawa 2008, s. 143-153.

53 D. PARKS: The "great writ"..., s. 356.

${ }^{54}$ W. Blackstone: Commentaries on the laws of England..., s. 125. 
bez zbędnej zwłoki (zob. VI poprawkę do Konstytucji USA), mające zapewnić wspomnianą już wcześniej niezwłoczność. W Wielkiej Brytanii limit zatrzymania wynosi 24 godziny. W przypadku spraw skomplikowanych może być ono przedłużone o kolejne 12 godzin $^{55}$, przy czym sumarycznie ujęty okres zatrzymania bez zgody sądu nie może przekroczyć 96 godzin, co jest limitem dotyczącym wyłącznie najcięższych przestępstw. Wyjątkiem jest $\mathrm{w}$ tym zakresie zatrzymanie na podstawie Terrorism Act. W razie podejrzenia popełnienia czynu o charakterze terrorystycznym organy ścigania mają aż 14 dni na zebranie materiału dowodowego potrzebnego do postawienia jednostce zarzutów ${ }^{56}$. Sytuacja wygląda podobnie $\mathrm{w}$ prawie kanadyjskim. Zgodnie z art. 503 ust. 1 kanadyjskiego kodeksu karnego ${ }^{57}$, zatrzymanemu należy przedstawić zarzuty w ciągu 24 godzin od fizycznego pozbawienia go wolności, a następnie postawić go przed sądem. Gdyby zaś okazało się to niemożliwe lub niecelowe, należy zatrzymanego zwolnić, ponieważ każde arbitralne i przekraczające zakreślony czas pozbawienie wolności stanowiłoby naruszenie zagwarantowanej jednostce wolności osobistej (art. 9 Kanadyjskiej Karty Praw i Swobód). Wyjątek w tym zakresie przewidziano jednak już w art. 503 ust. 1 lit. b przywołanego aktu, wskazując, że jeśli nie jest możliwe dostarczenie zatrzymanego do sądu w chwili upływu omawianego limitu, należy wykonać tę czynność, gdy tylko będzie to możliwe (as soon as possible). Przykładem takiej sytuacji jest zatrzymanie danej osoby w dzień wolny od pracy sądów, kiedy jej dostarczenie do sądu może się okazać możliwe dopiero w kolejnym dniu roboczym. Z kolei regulacje amerykańskie wymagają, aby oskarżony sensu largissimo stanął przed sądem w ciągu 48 godzin od czasu fizycznego pozbawienia wolności. Następnie sąd, po wysłuchaniu argumentów stron, decyduje o zasadności zarzutów albo o konieczności zebrania przez oskarżenie dodatkowego materiału dowodowego. Prokurator zobowiązany jest przedstawić sądowi zeznanie pod przysięgą (sworn statement), na którego podstawie uprawdopodobni popełnienie przez zatrzymanego zarzucanego mu przestępstwa. W praktyce owo zeznanie zapewniają zwykle funkcjonariusze policji (stanowej lub federalnej) biorący udziału w śledztwie albo dochodzeniu. Sąd ma wów-

${ }^{55}$ Zapisy Habeas Corpus Act przewidują, że w ciągu 24 godzin od fizycznego pozbawienia jednostki wolności powinno się jej przedstawić zarzuty. Ta zaś zdecyduje, czy kierować do sądu wniosek o wystawienie writ of habeas corpus i zainicjować kontrolę legalności zatrzymania. Ustawa stanowi, że pozbawiony wolności może w oczekiwaniu na proces przebywać w więzieniu maksymalnie do 20 dni, w zależności od odległości więzienia od budynku sądu (H. WaJs: Habeas Corpus Act..., s. 143-144).

${ }_{56}$ Being arrested: your rights. https://www.gov.uk/arrested-your-rights/how-long-youcan-be-held-in-custody [dostęp: 24.11.2020].

57 Criminal Code, R.S.C., 1985, c. C-46. https://www.canlii.org/en/ca/laws/stat/rsc1985-c-c-46/latest/rsc-1985-c-c-46.html\#sec83.3 [dostęp: 24.11.2020]. 
czas możliwość podjęcia decyzji o wyznaczeniu kaucji (mającej charakter depozytu gwarantującego stawienie się przed jednostkę w sądzie) bądź o tymczasowym aresztowaniu ${ }^{58}$. Należy jednak zaakcentować, że standard 48 godzin wynika z unormowań federalnych, w związku z czym regulacje wewnątrzstanowe mogą przewidywać krótsze maksymalne okresy pozbawienia wolności w związku z zatrzymaniem. Równocześnie wskazuje się, że aresztowanie nie powinno być dla jednostki zbyt inwazyjne. Jak przyjął Sąd Najwyższy USA w sprawie United States v. Sharpe, funkcjonariusze policji powinni wykonywać swoje obowiązki jak najszybciej, tak aby osoba aresztowana nie spędziła $\mathrm{w}$ areszcie więcej czasu niż jest to konieczne dla dokonania niezbędnych czynności procesowych ${ }^{59}$. Przywołane rozwiązania pokazują, że tego typu limity w rzeczywistości mogą się niekiedy okazać dość „elastyczne”, niemniej ocena zasadności ich ewentualnego wydłużenia każdorazowo należy do sądu.

Choć dla czytelnika z Europy - gdzie kara śmierci zasadniczo od pewnego czasu już nie obowiązuje ${ }^{60}$ - może się to wydawać co najmniej nieoczywiste, zasada habeas corpus wiąże się również z ochroną życia w jego dosłownym znaczeniu. W niektórych częściach USA, choć raczej w drodze wyjątku (np. w Teksasie), nadal możliwe jest orzeczenie za konkretne przestępstwo tzw. kary kapitalnej (capital punishment). W tamtejszym orzecznictwie podnosi się, że omawiana instytucja może pełnić funkcję niejako „ostatniej nadziei” dla ludzi, których konstytucyjne gwarancje zostały pogwałcone. Zasadę habeas corpus stosuje się w związku z tym często do spraw już osądzonych, inicjując tym samym ich ponowne rozpatrzenie pod kątem formalnym. Nie powinno wszak budzić wątpliwości, że w sytuacji orzeczenia kary śmierci konieczne jest zachowanie ostrożności procesowej ponad wszelką miarę, aby mieć pewność, że dochowano standardu prawnej ochrony życia ludzkiego ${ }^{61}$. Uzasadnione jest więc doszukiwanie się związku analizowanej instytucji z prawem do rzetelnego procesu. Wydaje się, że arbitralne odmówienie więźniom oczekującym na wykonanie orzeczonej kary śmierci możliwości skorzystania z tego

58 L. BONFIELD: American law and the American legal system in a nutshell. St. Paul 2006, s. 250 i nast.; Pre-trial detention custody time limits. Ensuring compliance in Malawi, s. 12. https://prisonstudies.org/sites/default/files/resources/downloads/malawi_custody_time_ limit_report_january_2013.pdf [dostęp: 24.11.2020].

${ }^{59}$ United States v. Sharpe, 470 U.S. 675 (1985). https://supreme.justia.com/cases/ federal/us/470/675/ [dostęp: 24.11.2020].

${ }^{60}$ Jak wynika z danych Amnesty International, w 2019 r. w Europie karę śmierci wykonano jedynie na Białorusi. Formalnie kara ta nie została zniesiona również w Rosji, jednak od lat obowiązuje tam stosowne moratorium. Kara śmierci 2019: Fakty i liczby. https://amnesty.org.pl/kara-smierci-2019-fakty-i-liczby/ [dostęp: 24.11.2020].

${ }^{61}$ Zob. Penry v. Lynaugh, 492 U.S. 302 (1989). https://supreme.justia.com/cases/federal/us/492/302/ [dostęp: 24.11.2020]. 
przywileju stanowiłoby naruszenie prawa przysługującego im zgodnie z V poprawką do Konstytucji USA (słusznie więc Hugo LaFayette Black doszukiwał się w filozoficznych i socjologicznych źródłach tego aktu podstaw gwarancji procesowych podejrzanego i oskarżonego ${ }^{62}$ ). W literaturze wskazuje się, że w przeszłości więźniowie wielokrotnie składali wnioski o przyznanie im writ of habeas corpus, co miało na celu jak najdalsze „odwleczenie” wykonania kary. Praktyka ta doprowadziła do przyjęcia, że więźniom oczekującym na wykonanie kary śmierci co do zasady przysługuje możliwość złożenia tylko jednego wniosku o ponowne rozpatrzenie formalnoprawnych aspektów związanych z legalnością pozbawienia wolności ${ }^{63}$.

Warto podkreślić, że uprawnienia wypływające z komentowanej instytucji wynikają z aktów o charakterze konstytucyjnym, tj. z Konstytucji USA, Kanadyjskiej Karty Praw i Swobód (będącej immanentną częścią kanadyjskiej konstytucji) oraz Wielkiej Karty Swobód, a także z dookreślających ją Bill of Rights i Habeas Corpus Act ${ }^{64}$. Mimo to zasada habeas corpus nie ma charakteru absolutnego. Częstokroć z treści samych konstytucji wynika możliwość zawieszenia jej stosowania. W amerykańskim prawie federalnym podstawę taką przewidziano $\mathrm{w}$ art. $1 \S 9$ zdanie 2 Konstytucji USA, zgodnie z którym: „Przywilej Habeas Corpus może być zawieszony tylko w przypadkach, gdy ze względu na bunt lub najazd wymagać tego będzie bezpieczeństwo publiczne” (tłum. - P.K.). Analogiczną regulację przewidziano w art. $33 \mathrm{w}$ zw. z art. 1 Kanadyjskiej Karty Praw i Wolności. W systemie brytyjskim znane są z kolei ustawy zawieszające stosowanie analizowanej zasady, zwane Habeas Corpus Suspension Act(s). W latach 1688-1817 do ich uchwalenia doszło aż pięciokrotnie, za każdym razem z uwagi na wyjątkową sytuację związaną ze znajdowaniem się w stanie wojny. Zawieszenie możliwości inwokowania tego przywileju każdorazowo powinno mieć charakter wyjątkowy. W XVII w. władze brytyjskie nadużywały uprawnienia do jego zawieszania, co skutkowało m.in. znaczącym wzrostem liczby aresztowań niezgodnych z prawem. Wprowadzano bowiem tzw. ustawy proskrypcyjne (Bills of Attainder), które umożliwiały wymierzanie kar w drodze aktu ustawodawczego, bez

${ }^{62}$ H.L. Black: A constitutional faith. New York 1969, s. 4-6.

${ }_{63}$ Por. R.V. Del CARMen: Criminal procedure..., s. 65-66.

${ }^{64}$ Wprawdzie Zjednoczone Królestwo nie posiada konstytucji w znaczeniu formalnym, jednak przyjmuje się, że określone akty - ze względu na ich estymę, przedmiot regulacji czy specyfikę organu, który je wydał - pełnią funkcję konstytucji w znaczeniu materialnym, regulując podstawowe zasady wykonywania władzy w państwie (M. Koszowski: Anglosaska doktryna precedensu. Porównanie z polska praktykq orzeczniczą. Warszawa 2009; zob. Podstawowe ustawy ustrojowe Zjednoczonego Królestwa Wielkiej Brytanii i Irlandii Pótnocnej. http://libr.sejm.gov.pl/tek01/txt/konst/brytania.html [dostęp: 24.11.2020]). 
przeprowadzania właściwego procesu sądowego ${ }^{65}$. W celu wyeliminowania możliwości stosowania takich praktyk, ojcowie założyciele Stanów Zjednoczonych wprowadzili do Konstytucji USA swoistą „klauzulę buforową", zakazującą wydawania wspomnianych ustaw, uniemożliwiając tym samym nadużywanie uprawnienia do zawieszania stosowania gwarancji habeas corpus ${ }^{66}$.

\subsection{Podsumowanie}

Gustave Le Bon mawiał, że idee starzeją się szybciej niż słowa. Wydaje się, że analiza ewolucji zasady habeas corpus na przestrzeni wieków prowadzi do zupełnie przeciwnych wniosków. Stanowiąc pierwotnie przywilej chroniący jedynie wąską grupę rycerstwa przed naruszeniem stanu ich posiadania, idea ta przekształciła się w międzynarodowy standard ochrony praw człowieka, chroniący przed bezprawnym pozbawieniem wolności bez wyroku sądowego. Opisywana zasada pełni obecnie funkcję swoistego bezpiecznika, zapobiegając nabraniu przez konkretne postępowanie cech procesu kafkowskiego. Choć oczywiście rozszerzenie jej stosowania na wszystkie grupy społeczne należy uznać za trafne, kwestia zakresu spraw objętych działaniem tego przywileju pozostaje w dalszym ciągu otwarta. O ile wątpliwości nie budzi stosowanie instytucji habeas corpus w sprawach stricte „kryminalnych”, o tyle w piśmiennictwie anglosaskim żywo dyskutowana jest celowość objęcia nią również postępowań związanych np. z ochroną zdrowia (fizycznego lub psychicznego). Podnosi się, że nie jest do końca jasne, czy uczestnicy tego typu procedur również są adresatami konstytucyjnego przywileju habeas corpus ${ }^{67}$.

W toku zaprezentowanych rozważań świadomie nie unikano odwołań do wątków historycznych. Robert James Sharpe wskazywał, że omawiany przywilej wywodzi się z angielskiego systemu common law ${ }^{68}$, a ten wszak $\mathrm{w}$ dalszym ciągu oparty jest $\mathrm{w}$ dużej mierze właśnie na rozwiązaniach historycznych. Jak podkreślano już wcześniej, interpretacji przepisów regulujących postępowanie habeas corpus (w tym zwłaszcza Konwencji) należy dokonywać z uwzględnieniem pierwowzoru tej instytucji, w związku z czym analizę historycznoprawną uznano za wręcz niezbędną dla umożliwienia Czytelnikowi prawidłowego umiejscowienia komentowanej zasady w systemie prawa.

${ }^{65}$ Por. H. Wajs: Habeas Corpus Act..., s. 143-153.

${ }^{66}$ W USA do takiego zawieszenia doszło np. na mocy decyzji prezydenta Abrahama Lincolna podjętej w czasie wojny secesyjnej (ibidem, s. 144).

${ }^{67}$ D.E. Hall: Criminal law and procedure. Clifton Park 2012, s. 588-590.

${ }^{68}$ R.J. Sharpe: Habeas corpus in Canada..., s. 241. 


\section{Wnioski}

Przedstawione zestawienie prowadzi do następujących spostrzeżeń: opisane systemy prawne różnią się $\mathrm{w}$ omawianym zakresie nawet pod względem definicyjnym. W polskiej nauce procesu karnego habeas corpus postrzega się raczej jako rodzaj procedury (perspektywa procesowa) lub zbiór uprawnień (perspektywa materialnoprawna), gdy tymczasem w państwach anglosaskich wyrażenie to ma charakter nieco bardziej „namacalny", oznaczając również specyficzny rodzaj decyzji sądowej (nakazu sądowego), writ of habeas corpus.

Uwagę przykuwa także odmienny charakter prawny procedur znanych $\mathrm{z}$ poszczególnych systemów, jako że w systemie common law przywilej habeas corpus oparty jest głównie na rozwiązaniach cywilnoprawnych. To zaś niesie określone konsekwencje, w tym przede wszystkim prowadzi do odmiennego niż w prawie polskim rozkładu ciężaru dowodu. W polskim prawie karnym procesowym zasadniczo to na organie postępowania przygotowawczego spoczywa ciężar udowodnienia okoliczności opisanych np. we wniosku o zastosowanie tymczasowego aresztowania. Z kolei w systemie prawa precedensowego, właśnie z uwagi na cywilnoprawny charakter analizowanego trybu, udowodnienie nieprawidłowości w zakresie pozbawienia wolności należy do oskarżonego sensu largissimo ${ }^{69}$. Pismo inicjujące ten tryb przybiera w krajach anglosaskich jednolitą postać pozwu i wnoszone jest zawsze przez jednostkę. W modelu polskim, w zależności od formy pozbawienia wolności, omawiane postępowanie rozpoczyna się zażaleniem (zatrzymanie) albo wnioskiem (tymczasowe aresztowanie), składanym bądź to przez zatrzymanego lub jego obrońcę (zatrzymanie), bądź to przez prokuratora (tymczasowe aresztowanie).

Obca rodzimemu modelowi procesu karnego jest również możliwość kwestionowania legalności pozbawienia wolności za sprawą komentowanej procedury już po wydaniu prawomocnego wyroku skazującego. Wydaje się jednak, że węższe granice temporalne przywileju habeas corpus same przez się nie wpływają na pogorszenie pozycji procesowej oskarżonego sensu largissimo na gruncie prawa polskiego. W przypadku najbardziej rażących naruszeń prawa skazany może wszak skorzystać jeszcze z nadzwyczajnych środków zaskarżenia, w tym zwłaszcza z kasacji, $\mathrm{w}$ której - podobnie jak ma to miejsce w systemie prawa precedensowego - możliwe jest odniesienie się także do formalnoprawnych aspektów sprawy (choć równocześnie warto odnotować, że wniesienie tego typu skargi obwarowane jest licznymi ograniczeniami).

${ }^{69}$ R.J. BaCigal: Criminal law and procedure. An overview. Clifton Park 2009, s. 39. 
Analiza systemów prawnych państw common law pokazuje, że swoisty automatyzm sądowej kontroli legalności zatrzymania, choć w myśl zaprezentowanego $\mathrm{w}$ pracy ujęcia jest wymagany przez art. 5 ust. $3 \mathrm{EKPCz}$, nie należy do istoty instytucji habeas corpus. Nawet jednak pomijając na moment argument dotyczący niezgodności rozwiązań polskich z Konwencją, należy się z całą stanowczością zgodzić z wysuwanymi w piśmiennictwie postulatami uniezależnienia sądowej kontroli zatrzymania od złożenia stosownego wniosku przez osobę pozbawioną wolności. Wydaje się, że znany z krajów anglosaskich brak automatyzmu w tym zakresie wynika głównie z zasygnalizowanego już wcześniej oparcia tamtejszej zasady habeas corpus na rozwiązaniach cywilnoprawnych. W nowoczesnych demokracjach liberalnych postępowanie cywilne ze swej istoty bazuje przecież na dyspozycyjności (rozporządzalności) ${ }^{70}$, co w połączeniu ze wspomnianym rozkładem ciężaru dowodu dostatecznie uzasadnia przyjęcie w systemie common law wnioskowego charakteru analizowanego przywileju. Skoro to wyłącznie pozbawiony wolności powinien przedstawić sądowi dowody wskazujące na nielegalność określonej czynności organu ścigania, to inicjowanie tego trybu z urzędu, niejako wbrew jego woli, wydaje się pozbawione racji, a z punktu widzenia ekonomicznej analizy prawa prowadzi co najwyżej do zmarnotrawienia publicznych środków i czasu. Nie powinno budzić wątpliwości, że argumenty te nie dotyczą polskiego porządku prawnego, w którym procedura habeas corpus „obsługiwana” jest przez prawo karne procesowe, de lege lata oparte przecież $\mathrm{w}$ dużej mierze na inkwizycyjności, działaniu z urzędu i paternalizmie.

Za rozwiązaną trafniej w prawie polskim należy z kolei uznać kwestię maksymalnego czasu trwania pozbawienia wolności bez zgody sądu. Jak wskazywano, w wielu krajach systemu prawa precedensowego, inaczej niż ma to miejsce zgodnie $\mathrm{z}$ art. 41 ust. 3 zdanie 2 i 3 Konstytucji RP, limit stosowania zatrzymania nie jest sztywny, przez co w określonych sytuacjach organom ścigania zezwala się na dłuższe niż zwykle pozbawianie jednostki wolności przy braku kontroli ze strony niezawisłego organu. Rozwiązanie to można próbować uzasadnić ciężarową dywersyfikacją czynów karalnych, tj. ideą, zgodnie z którą organy państwa nie powinny dysponować takim samym czasem na zgromadzenie dowodów pozwalających na skuteczne złożenie wniosku o zastosowanie tymczasowego aresztowania $\mathrm{w}$ przypadku przestępstw poważnych oraz zupełnie baga-

70 W. Berutowicz: Postępowanie cywilne w zarysie. Warszawa 1984, s. 283; W. SIEDLECKI, w: Postępowanie cywilne. Część ogólna. Red. J. JodŁowski, W. Siedlecki. Warszawa 1958, s. 152; jak wskazywał Henryk Mądrzak, to właśnie dyspozycyjność w największym stopniu świadczy o odmienności postępowania cywilnego względem innych rodzajów postępowań (H. MąDrzaK, w: Postępowanie cywilne. Red. H. MąDrZaK. Warszawa 2003, s. 57). 
telnych. Pozwoliłoby to również w większym stopniu zabezpieczyć interesy pokrzywdzonego, który nie powinien przecież ponosić negatywnych konsekwencji bezradności samego państwa. Należy jednak pamiętać, że na wstępnym etapie procesu karnego organy postępowania przygotowawczego mają obowiązek jedynie uprawdopodobnienia sprawstwa i winy oskarżonego sensu largissimo, a nie ich udowodnienia (art. 244 § 1 k.p.k. uznaje za przesłankę zatrzymania uzasadnione przypuszczenie popełnienia przestępstwa, z kolei art. 249 § 1 in fine k.p.k. wymaga dla zastosowania środków zapobiegawczych dużego prawdopodobieństwa jego popełnienia). Jeśli organy ścigania nie dysponują materiałem, który mógłby przekonać sąd o konieczności zastosowania tymczasowego aresztowania, i wiedzą, że nie są w stanie go pozyskać w ciągu 48 godzin od chwili zatrzymania, to być może powinny się co najmniej wstrzymać z decyzją o pozbawieniu jednostki wolności. Warto również zauważyć, że uzależnienie maksymalnego czasu trwania pozbawienia wolności bez zgody sądu od powagi analizowanego czynu mogłoby generować patologiczne zjawisko manipulowania przyjętą wstępnie kwalifikacją prawną czynu na potrzeby wydłużenia czasu do wniesienia skutecznego wniosku o zastosowanie tymczasowego aresztowania (de lege lata na problem ten zwraca się uwagę w kontekście przesłanki z art. 258 § 2 k.p.k.). Zaletą rodzimego rozwiązania jest więc jego gwarancyjność, dzięki której zatrzymany jest w stanie z góry przewidzieć maksymalny czas trwania jego niekontrolowanej przez sąd inkarceracji. Równocześnie przyczynia się ona do zmotywowania organów ścigania do efektywnego wykorzystania pozostałego im czasu, nie zaś do poszukiwania sposobów na jego wydłużenie.

\section{Bibliografia}

\section{Literatura}

Bacigal R.J.: Criminal law and procedure. An overview. Clifton Park 2009.

Berutowicz W.: Postępowanie cywilne w zarysie. Warszawa 1984.

BLACK H.L.: A constitutional faith. New York 1969.

Blackstone W.: Commentaries on the laws of England. A facsimile of the first edition of 1765-1769. Vol. 1. Chicago 1979.

BONFIELD L.: American law and the American legal system in a nutshell. St. Paul 2006.

CARMEN R.V. DEL: Criminal procedure. Law and practice. Belmont 2007.

Снurch W.S.: A treatise of the writ of habeas corpus. Including jurisdiction, false imprisonment, writ of error, extradition, mandamus, certiorari, judgments, etc. With practice and forms. San Francisco 1886.

Cora Ł.: Zatrzymanie osoby $w$ polskim procesie karnym. Analiza dogmatyczno-prawna. Warszawa 2015. 
Dressler J., Thomas III G.C.: Criminal procedure. Prosecuting crime. St. Paul 2006.

EICHSTAEDT K.: Czynności sądu w postępowaniu przygotowawczym w polskim prawie karnym. Warszawa 2008.

English historical documents. Vol. 2: 1042-1189. Eds. D.C. Douglas, G.W. GreEnaway. London 1981.

GIFIS S.H.: Law dictionary. New York 1996.

Gronowska B.: Wolność i bezpieczeństwo osobiste $w$ sprawach karnych $w$ świetle standardów Rady Europy (implikacje praktyczne dla prawa polskiego). Torun 1996.

Hall D.E.: Criminal law and procedure. Clifton Park 2012.

HeRmelińsKi W., Nita-ŚwiatŁowsKa B.: Kilka uwag o prawie do obrony $w$ zwiazku $z$ nowelizacja Kodeksu postępowania karnego z 2016 roku. „Palestra” 2016, nr 9.

Hofmański P., w: Konwencja o Ochronie Praw Człowieka i Podstawowych Wolności. T. 1: Komentarz do artykułów 1-18. Red. L. GARLICKI. Warszawa 2010.

HoFMAŃsKI P.: Europejskie standardy $w$ zakresie kontroli stosowania przymusu $w$ procesie karnym a reforma kodeksu postępowania karnego. W: Problemy kodyfikacji prawa karnego. Księga ku czci Profesora Mariana Cieślaka. Red. S. WaLtoś. Kraków 1993.

Hofmański P., Wróbel A., w: Konwencja o Ochronie Praw Człowieka i Podstawowych Wolności. T. 1: Komentarz do artykułów 1-18. Red. L. GarLICKI. Warszawa 2010 .

Hofmański P., ZabŁocki S.: Pozbawienie wolności w toku procesu karnego. Wybrane aspekty konstytucyjne i prawnomiędzynarodowe. W: Rzetelny proces karny. Księga jubileuszowa Profesor Zofii Świdy. Red. J. SKonuPKa. Warszawa 2009.

HoŁDA Z.: Z problematyki gwarancji procesowych podejrzanego $w$ świetle konstytucji USA. „Annales Universitatis Mariae Curie-Skłodowska. Sectio G” 1983, nr 9.

HuRnARD N.D.: The jury of presentment and the Assize of Clarendon. „The English Historical Review" 1941, no. 56.

IZYDORCZYK J.: Stosowanie tymczasowego aresztowania $w$ kontekście instytucji Habeas Corpus, prawo do obrony. W: P. WilińsKi et al.: Stosowanie tymczasowego aresztowania $w$ Polsce. Analiza i rekomendacje. Raport. Lublin-PoznańWarszawa 2008.

IZYDORCZYK J.: Stosowanie tymczasowego aresztowania $w$ polskim postępowaniu karnym. Kraków 2002.

IzYDORCZYK J.: Zasada Habeas Corpus jako wzorzec respektowania prawa do wolności a aktualne prawo polskie. W: Verba volant, scripta manent. Proces karny, prawo karne skarbowe i prawo wykroczeń po zmianach z lat 2015-2016. Ksiega pamiątkowa poświęcona Profesor Monice Zbrojewskiej. Red. T. GrzegorczyK, R. Olszewski. Warszawa 2017.

JAWORSKI I.: Zarys powszechnej historii państwa i prawa. Warszawa 1978.

Judicial and statutory definitions of words and phrases. St. Paul 1914. 
KARDAS P.: Standard rzetelnego procesu a prawo wgladu do akt sprawy w postępowaniu $w$ przedmiocie tymczasowego aresztowania, czyli historia jednej nowelizacji. „Prokuratura i Prawo” 2010, nr 1-2.

KARDAS P.: Upływ określonego $w$ art. 41 ust. 3 Konstytucji $i w$ art. 248 \& 2 k.p.k. 24-godzinnego terminu a możliwość wydania postanowienia o tymczasowym aresztowaniu. „Czasopismo Prawa Karnego i Nauk Penalnych” 2008, z. 1.

Kardas P., WilińsKi P.: O niekonstytucyjności odmowy dostępu do akt sprawy $w$ postępowaniu $w$ przedmiocie tymczasowego aresztowania. „Palestra” 2008, nr 7-8.

Kosonoga J.: Dozór Policji jako środek zapobiegawczy w polskim procesie karnym. Warszawa 2008.

Koszowski M.: Anglosaska doktryna precedensu. Porównanie z polska praktykq orzecznicza. Warszawa 2009.

MądrzaK H., w: Postępowanie cywilne. Red. H. MądrzaK. Warszawa 2003.

Majcher S., StachursKi D.: Sądowa kontrola zatrzymania $w$ świetle Konstytucji RP. „Państwo i Prawo” 2006, nr 4.

MuRZYNOWSKI A.: Kilka uwag dotyczacych realizacji paktów praw człowieka $w$ polskim prawie karnym procesowym. "Acta Universitatis Wratislaviensis. Prawo” 1990, t. 173.

MurzYNOWsKi A.: Refleksje na temat zmian w przepisach dotyczacych stosowania tymczasowego aresztowania. „Prokuratura i Prawo” 1997, nr 1.

Nowicki M.A.: Wokół Konwencji Europejskiej. Krótki komentarz do Europejskiej Konwencji Praw Człowieka. Warszawa 2006.

PARKS D.: The "great writ" reinvigorated? Habeas corpus in contemporary Canada. „Manitoba Law Journal” 2012, no. 1.

SHARPE R.J.: Habeas corpus, extradition and the burden of proof: The case of the man who escaped from Devil's Island. „The Cambridge Law Journal” 1990, no. 3.

Sharpe R.J.: Habeas corpus in Canada. „Dalhousie Law Journal” 1975, no. 2.

Siedlecki W., w: Postępowanie cywilne. Część ogólna. Red. J. JodŁowsKi, W. Siedlecki. Warszawa 1958.

Skorupka J., w: Kodeks postępowania karnego. Komentarz. Red. J. SKorupKA. Warszawa 2020.

SKorupKa J.: Access to detainees' files in the light of Directive 2012/13/EU of the European Parliament and of the Council of 22 May 2012 on the right to information in criminal proceedings and under Polish law. „Ius Novum” 2017, no. 2.

SKORUPKA J.: Granice ingerencji $w$ wolność osobista jednostki i prawo do nieobciażania się $w$ postępowaniu karnym. W: Model dopuszczalnej ingerencji $w$ prawa $i$ wolności jednostki $w$ procesie karnym - The Model of acceptable interference with the rights and freedoms of an individual in the criminal process. Red. J. SKORUPKA. Warszawa 2019.

SKORUPKA J.: Konstytucyjny $i$ konwencyjny standard tymczasowego aresztowania. „Państwo i Prawo” 2007, nr 7.

SKorupKa J.: Udostępnienie akt sprawy podejrzanemu. "Prokuratura i Prawo" 2007, nr 5. 
SKorupKa J.: W kwestii dostępu tymczasowo aresztowanego do wniosku $w$ przedmiocie tymczasowego aresztowania oraz do akt sprawy $w$ postępowaniu przygotowawczym na marginesie orzeczeń sądów powszechnych. „Palestra” 2008, nr 7-8.

SKORUPKA J.: Zatrzymanie procesowe osoby podejrzanej. „Prokuratura i Prawo” 2007, nr 11.

SKręTOWICZ E.: Kodeks postępowania karnego. Wprowadzenie. Kraków 1996.

SÓJKA-ZIELIŃsKa K.: Cesare Beccaria a ochrona praw człowieka w procesie karnym. „Analecta. Studia i Materiały z Dziejów Nauki” 1995, z. 2.

Wajs H.: Habeas Corpus Act z 1679 roku. W: Ksiega jubileuszowa Rzecznika Praw Obywatelskich. T. 1: Pomniki praw człowieka $w$ historii. Red. H. WaJs, R. WitKowsKi. Warszawa 2008.

WAŁACH J.: „Uprawnienia procesowe zatrzymanego i tymczasowo aresztowanego w świetle zasady prawa do obrony" [rozprawa doktorska]. Opieka nauk. C. Kulesza. Katedra Postępowania Karnego, Wydział Prawa, Uniwersytet w Białymstoku, Białystok 2014. https://repozytorium.uwb.edu.pl/jspui/bitstream/11320/3129/1/praca\%20doktorska.pdf.

Waltoś S., Hofmański P.: Proces karny. Zarys systemu. Warszawa 2013.

WĄSEK-WIADEREK M.: Dostęp do akt sprawy oskarżonego tymczasowo aresztowanego i jego obrońcy $w$ postępowaniu przygotowawczym - standard europejski a prawo polskie. „Palestra” 2003, nr 3-4.

WiLIŃsKi P.: Odmowa dostępu do akt sprawy w postępowaniu przygotowawczym. „Prokuratura i Prawo” 2006, nr 11.

\section{Akty prawne}

Konstytucja Stanów Zjednoczonych Ameryki. http://libr.sejm.gov.pl/tek01/txt/ konst/usa.html [dostęp: 24.11.2020].

A consolidation of the constitution acts - Codification administrativedes lois constitutionnelles. https://laws-lois.justice.gc.ca/eng/Const/page-15.html [dostęp: 24.11.2020].

Criminal Code, R.S.C., 1985, c. C-46. https://www.canlii.org/en/ca/laws/stat/rsc1985-c-c-46/latest/rsc-1985-c-c-46.html\#sec83.3 [dostęp: 24.11.2020].

Ustawa z dnia 2 kwietnia 1997 r. - Konstytucja Rzeczypospolitej Polskiej. Dz.U. 1997, nr 78, poz. 483, Dz.U. 2001, nr 28, poz. 319, Dz.U. 2006, nr 200, poz. 1471, Dz.U. 2009, nr 114, poz. 946.

Ustawa z dnia 6 czerwca 1997 r. - Kodeks postępowania karnego. Dz.U. 2020, poz. 30 ze zm.

Ustawa z dnia 30 kwietnia 2020 r. o zmianie ustawy - Kodeks postępowania cywilnego oraz niektórych innych ustaw. Dz.U. 2020, poz. 956.

Konwencja o Ochronie Praw Człowieka i Podstawowych Wolności sporządzona w Rzymie dnia 4 listopada 1950 r., zmieniona następnie Protokołami nr 3, 5 i 8 oraz uzupełniona Protokołem nr 2. Dz.U. 1993, nr 61, poz. 284 ze zm.

Konwencja wiedeńska o prawie traktatów sporządzona w Wiedniu dnia 23 maja 1969 r. Dz.U. 1990, nr 74, poz. 439. 
Dyrektywa Parlamentu Europejskiego i Rady 2012/13/UE z dnia 22 maja 2012 r. w sprawie prawa do informacji w postępowaniu karnym. Dz.Urz. UE L nr 142.

\section{Orzecznictwo}

Orzeczenie Sądu Najwyższego z 27 stycznia 1921 r. LEX nr 1674571.

Wyrok Europejskiego Trybunału Praw Człowieka z 29 listopada 1988 r. w sprawie Brogan i in. przeciwko Zjednoczonemu Królestwu. Seria A nr 145-B, § 58.

Wyrok Europejskiego Trybunału Praw Człowieka z 25 marca 1999 r. w sprawie Nikolova przeciwko Bułgarii. Skarga nr 31195/96, § 58. www.echr.coe.int.

Wyrok Europejskiego Trybunału Praw Człowieka z 4 lipca 2000 r. w sprawie Niedbała przeciwko Polsce. Skarga nr 27915/95, § 49. www.echr.coe.int.

Wyrok Europejskiego Trybunału Praw Człowieka z 25 czerwca 2002 r. w sprawie Migoń przeciwko Polsce. Skarga nr 24244/94, § 68. Legalis.

Wyrok Europejskiego Trybunału Praw Człowieka z 3 października 2006 r. w sprawie McKay przeciwko Zjednoczonemu Królestwu. Skarga nr 543/03, § 34. www.echr.coe.int.

Wyrok Europejskiego Trybunału Praw Człowieka z 18 marca 2008 r. w sprawie Ladent przeciwko Polsce. Skarga 11036/03, § 74. www.echr.coe.int.

Wyrok Europejskiego Trybunału Praw Człowieka z 26 listopada 2013 r. w sprawie Emilian-George Igna przeciwko Rumunii, 26 listopada 2013 r. Skarga nr 21249/05, § 31-33. www.echr.coe.int.

Wyroku Trybunału Konstytucyjnego z dnia 6 grudnia 2004 r. SK 29/04, OTK-A 2004, nr 11, poz. 114.

Wyrok Trybunału Konstytucyjnego z dnia 3 marca 2008 r. K 42/07, OTK-A 2008, nr 5, poz. 77.

United States v. Sharpe, 470 U.S. 675 (1985). https://supreme.justia.com/cases/ federal/us/470/675/ [dostęp: 24.11.2020].

Penry v. Lynaugh, 492 U.S. 302 (1989). https://supreme.justia.com/cases/federal/ us/492/302/ [dostęp: 24.11.2020].

Postanowienie Trybunału Konstytucyjnego z dnia 27 stycznia 2004 r. SK 50/03, OTK-A 2004, nr 1, poz 6.

\section{Źródła internetowe}

Being arrested: your rights. https://www.gov.uk/arrested-your-rights/how-long-you -can-be-held-in-custody [dostęp: 24.11.2020].

Habeas corpus. Legal Information Institute. https:/www.law.cornell.edu/wex/ habeas_corpus [dostęp: 18.08.2021].

Kara śmierci 2019: Fakty i liczby. https://amnesty.org.pl/kara-smierci-2019-faktyiliczby/ [dostęp: 24.11.2020].

Podstawowe ustawy ustrojowe Zjednoczonego Królestwa Wielkiej Brytanii i Irlandii Pótnocnej. http://libr.sejm.gov.pl/tek01/txt/konst/brytania.html [dostęp: 24.11.2020].

Pre-trial detention custody time limits. Ensuring compliance in Malawi, s. 12. https://prisonstudies.org/sites/default/files/resources/downloads/malawi_ custody_time_limit_report_january_2013.pdf [dostęp: 24.11.2020]. 